\title{
Review of antimicrobial administration in cases of proven bacteraemia in adult patients at one London teaching hospital
}

\author{
A Myers ${ }^{1 *}, \mathrm{~J} \mathrm{Hatcher}^{2}$ \\ From ESICM LIVES 2015 \\ Berlin, Germany. 3-7 October 2015
}

\section{Introduction}

The death of 12 year old Rory Staunton led to a U.S. Senate Hearing on Sepsis (Sept 2013). Rory's Regulations (part of New York State Law) state that evidence-based protocols must be used in identification and management of sepsis. In the UK, practice is guided by the Surviving Sepsis campaign [1]. Timely and appropriate antibiotic administration is of fundamental importance [2].

\section{Objectives}

1) To assess when septic patients receive antibiotics in a London teaching hospital. A subset of septic patients were reviewed: those with proven bacteraemia.

2) Are appropriate antimicrobials administered?

\section{Methods}

A retrospective review of bacteraemic adults with sepsis was carried out at St Mary's Hospital during May, June and July 2014. Data was obtained from patient notes, observation and drug charts, individual patients, the medical teams, and the microbiology laboratory. Record was made of demographics, time of presentation with sepsis, time of recognition, timing and choice of antimicrobial, and outcomes.

\section{Results}

42 cases were reviewed. 13 presented with severe sepsis and 4 out of the 42 eventually died of sepsis. A third received antibiotics within an hour and a third in 2-3hrs. 7 patients waited more than 9hrs, 3 of whom died. E.coli was the responsible organism in $45 \%$ of cases, Staphylococci accounted for $19 \%$ and Streptococci $12 \%$. In $75 \%$,

'King's College Hospital, London, United Kingdom

Full list of author information is available at the end of the article initial suspicion of source was correct. Antimicrobials were prescribed according to protocol or microbiology advice in $83 \%$. Antibiotic therapy was altered following pathogen identification in $55 \%$ of cases. Resistance mechanisms were present in $15 \%$ of gram negatives (AMP C or ESBL). Reasons for delay in receiving antimicrobials included: late recognition; complex presentation; antibiotics not administered at the time of prescription; no stat dose prescribed.

\section{Conclusions}

Most cases were recognised and treated appropriately within 3 hours. Some, however, had an unacceptably long delay. Most patients survived their bacteraemia and did not require ICU admission. Ward doctors are generally good at assessing the likely source of sepsis and most use guidelines or specialist advice to guide therapy. Management could be improved by encouraging doctors to administer antibiotics personally at the time of assessment and to measure lactate, especially when presentation is atypical. Most organisms are sensitive and unnecessary broadening of empiric antibiotic therapy beyond guidelines is not required. However, due to a significant minority of resistant pathogens, close liaison with Microbiology is recommended.

\section{Authors' details}

${ }^{1}$ King's College Hospital, London, United Kingdom. ${ }^{2}$ Imperial College,

Department of Microbiology, London, United Kingdom.

\section{Published: 1 October 2015}

\section{References}

1. Dellinger RP, Levy MM, Rhodes A, Annane D, Gerlach H, Opal SM, et al: Surviving Sepsis Campaign: International guidelines for management of severe sepsis and septic shock: 2012. Crit Care Med 2013, 41(2):580-637. (c) 2015 Myers et al.; This is an Open Access article distributed under the terms of the Creative Commons Attribution License (http:// creativecommons.org/licenses/by/4.0), which permits unrestricted use, distribution, and reproduction in any medium, provided the original work is properly cited. 
2. Kumar A, Roberts D, Wood KE, Light B, Parrillo JE, Sharma S, et al: Duration of hypotension before initiation of effective antimicrobial therapy is the critical determinant of survival in human septic shock. Crit Care Med 2006, 34(6):1589-1596.

doi:10.1186/2197-425X-3-S1-A406

Cite this article as: Myers and Hatcher: Review of antimicrobial administration in cases of proven bacteraemia in adult patients at one London teaching hospital. Intensive Care Medicine Experimental 2015 3(Suppl 1):A406.

\section{Submit your manuscript to a SpringerOpen ${ }^{\mathcal{O}}$ journal and benefit from:}

- Convenient online submission

- Rigorous peer review

- Immediate publication on acceptance

- Open access: articles freely available online

- High visibility within the field

- Retaining the copyright to your article

Submit your next manuscript at $\gg$ springeropen.com 